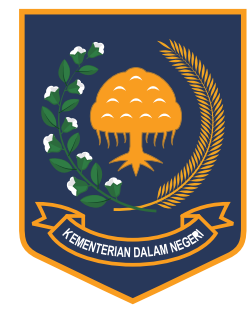

http://jurnal.kemendagri.go.id/index.php/jbp/index

\title{
IMPLEMENTATION QUALITY LEVEL of Health Public Service Policy in Banten Province Local Hospital (RSUD)
}

\author{
Yunia Rahayuningsih ${ }^{1, *}$, Yusniah Anggraini ${ }^{2}$, Listyaningsih ${ }^{3}$ \\ ${ }^{1,2}$ Regional Development Planning Board of Banten Province \\ Jl. Syekh Nawawi Al Bantani, Palima Serang \\ Serang 42127, Indonesia \\ ${ }^{3}$ Faculty of Social and Political Sciences of Sultan Ageng Tirtayasa University \\ Jl. Raya Serang-Jakarta KM 4, Serang, Banten
}

Received: 31 January 2018; Accepted: 6 April 2018; Published online: 12 May 2018

DOI: $10.21787 /$ jbp.10.2018.121-134

\begin{abstract}
Public Hospital (RSUD) of Banten Province, as the Province Referral Hospital, is required to always improve the quality of service in every line to achieve excellent service and also to give satisfaction to the public. Public satisfaction is one of the goals that must be considered by Banten Province Public Hospital because one indicator in achieving the success of health services is the achievement of public satisfaction. On this basis, it is important for the Banten Province Public Hospital to make measurements on the public satisfaction. Related to that, this study aims to find out the quality of public services in Banten Province Public Hospital, which is measured through Public Satisfaction Index (IKM), including problems faced in the provision of public health services in Banten Province Public Hospital. The research method used is survey method with a quantitative descriptive approach. The data is obtained through questionnaires, observations, and documentation. The sample size is 100 people, which is determined by quota sampling technique. The results showed that quantitatively, the quality of public service in Banten Province Public Hospital based on Public Satisfaction Index reached 75.71, which is qualitatively categorized as good. Although it has been categorized as good, of the ten elements assessed, there are some elements that need to get serious attention, namely elements of information, complaint handling, the behavior of service personnel, service time, and supporting elements.
\end{abstract}

Keywords: Quality, Health Service, Public Satisfaction

\section{INTRODUCTION}

Health is a human right and one of the elements of welfare that must be fulfilled in accordance with the ideals of the Indonesian nation as defined in Pancasila and the Constitution of the Republic of Indonesia of 1945. Then, in Law Number 36 of 2009 on Health, it explained that the government as a public service provider is responsible for the availability of all forms of health efforts that are of quality safe, efficient, and affordable.

With regards to the above, then a quality health service is one measure of satisfaction that affects the patient's desire to return to the institution that provides effective health services. Pasolong (2015) also mentioned that the decision of a consumer to consume or not to consume goods or services is influenced by many factors, among other is the perception of quality or service quality.

The definition of quality as explained by Tjiptono (2016) is a dynamic condition associated with products, services, people, processes and environments that meet or exceed expectations. Meanwhile, service according to Gronroos in Ratminto \& Winarsih (2016) is an activity that is invisible (not palpable) that occurs as a result of interaction between consumers with employees or other things provided by a company as the service provider to solve the problem of consumers/ customers.

The quality of services provided by the provider

\footnotetext{
* Corresponding Author

Phone : +62 8987989944

Email : yuniarahayuningsih@gmail.com
} 
(service provider) depends on the perception of consumers or services provided. However, it cannot be denied that health services, especially from the public sector, still have many obstacles, especially in terms of service quality. The level of public satisfaction with services from the public sector is still low, and this is evidenced by some research results on the quality of health services in various regions. Pundenswari (2017) in the result of her research explained that the quality of public services in Puskesmas is still low on aspects of tangible, reliability, responsiveness, assurance, and empathy. While Supartiningsih (2017) emphasizes the tangible and assurance aspects that are still low in-hospital services. However, Hubung (2015) only sees that aspects of empathy on health personnel in providing services are still not good/low.

The result of the research by Saptawan \& Nengyanti (2014) also shows that the quality of public health service according to the respondent's perception is lower than what is expected by the respondents (patients), so what needs to be done is to strengthen the reliability variable chains and then continued with empathy, responsiveness, assurance and tangibles. The result of this study differs from the results of Ulfa \& Zulkarnain (2016) research which states that the dimensions of reliability and responsiveness are considered less important for patients. Patients are not satisfied only with the dimensions of reliability, responsiveness, assurance, and empathy. In addition, there is a gap between patient perception and expectation in health service quality, and the lowest is health service from assurance aspect (Herawan, Hutabarat, \& Gustopo, 2017).

Especially for the quality of maternal health services, it is still found to be relatively low quality because it is related to the low utilization of maternal health services. Limited resources and health services, health facilities and infrastructure, and obstacles in the implementation on the delivery of maternity guarantee (Jampersal) program are the main cause of the low-quality services (Media, 2014). In relation to the National Health Insurance (JKN) service, there are still patients who are less satisfied, because the examination room in RSUD is considered less spacious and comfortable, and the equipment is considered not yet sophisticated and incomplete. (Dumupa, Harno, \& Budi, 2014).

In terms of strategy, according to Arisandy (2015), the strategy used by the Health Office still has many shortcomings, i.e. there are still people who do not understand the existence of a place for the service complaints. Therefore, the responses and feedback from service users are insufficient and will result in lack of input in improving the quality of services.

The condition in Banten Province Public
Hospital is not much different from health service condition as explained by the results of the research above, where the health service performance in this area is still considered low. This is related to BPJS patient registration counter that only has one officer who is available, and the service hour is only up to 12.00 WIB. In addition, the IGD and ICU spaces have not been operationalized, including the presence of messy health equipment, the absence of generators, wastewater treatment plant (IPAL), buildings, and billion rupiahs valued equipment not being used. There are still many shortcomings in terms of service, for example, at the registration desk is only open until 12 noon. What if there are people from far, who just arrive at the hospital in the afternoon. Many people are sad to see the condition of Banten Province Public Hospital, especially when they see the facilities and services, including limited inpatient space available (Preliminary Survey results in Secretariat Department of Banten Province Health Office, 2017). The condition is only observed from one aspect of health services alone, and not yet look at the overall health care aspects of the Banten Province Public Hospital. In order to determine whether health services provided are good or bad, they need are measured through the IKM on all aspects of health-related services.

With reference to the above descriptions, then the problem to be solved in this research is Public Satisfaction Index on health services at Banten Province Public Hospital.

\section{Method}

The research was conducted at Banten Province General Hospital. The research method used is survey method with a quantitative descriptive approach. The data were collected through questionnaires distributed to a number of randomly selected respondents. The sample size is 100 people, which is determined by quota sampling technique.

The data analysis is divided into two, namely descriptive data analysis and calculation analysis of Public Satisfaction Index (IKM) which refers to the Regulation of the Minister of Administrative and Bureaucratic Reform No. 16 of 2014 on Guidelines for Public Satisfaction Survey (there are 9 dimensions of public services) and Ministerial Decree Regulation of the Minister of Administrative and Bureaucratic Reform of the Republic of Indonesia Number 25 of 2004 on measurement guidelines of IKM.

\section{RESULTS AND DISCUSSION}

\section{A. Research Location Description}

Banten Province Public Hospital hereinafter abbreviated as RSUD Banten is a Unit of Regional 
Device which provides public health service. It has the duty to provide full-scale personal health services by prioritizing treatment and recovery without neglecting health improvement and disease prevention through the provision of inpatient, outpatient, emergency, medical, and medical support services.

The construction of Banten Public Hospital started in the 2007 budget year as one of the efforts made by the Provincial Government of Banten in providing optimal health services, especially health in Banten community. Due to the growing of Banten as a province, the more complex the health problems faced.

Banten Public Hospital, which was inaugurated on October 4, 2013, by the Vice Governor of Banten, is one of the governmental entity of Banten Province which is responsible in the field of Health, especially in terms of referral or advanced health services. In connection with its function as a Banten Provincial hospital, Banten Public Hospital is required to always improve the quality and service quality in every line, so that each program is directed towards efforts to achieve the goals as stated in the Vision and Mission of Banten General Hospital, in accordance with the ideals and expectations, especially from the people in Banten Province. (https://rsud.bantenprov. go.id/)

To carry out its main tasks, RSUD Banten has the following functions: (1) Implementation of medical and non-medical services, (2) Implementation of medical and non-medical support services, (3) Organizing referral services, (4) Implementation of education and training, and (5) Administration of public administration and finance (Secretariat of Banten Public Hospital, 2017).

\section{B. Respondents Profile}

The respondents in this study are people who come directly to Banten Hospital to get health services. Respondents were interviewed while visiting the hospitals. Then, the respondents were identified by age, gender, education level, type of

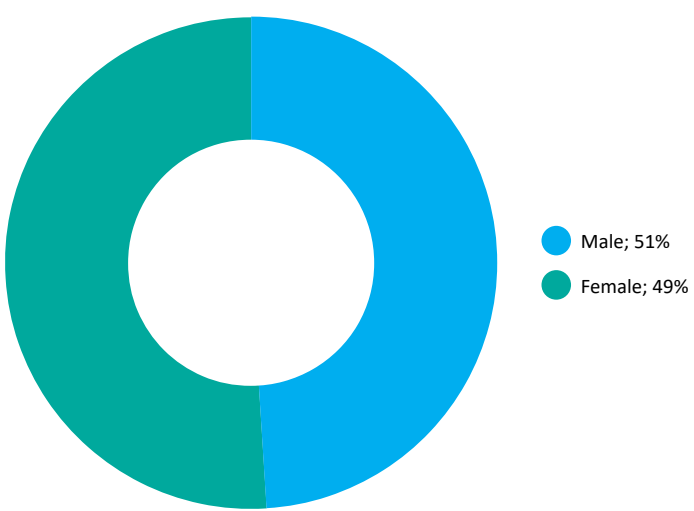

Figure 1. Respondents based on Gender

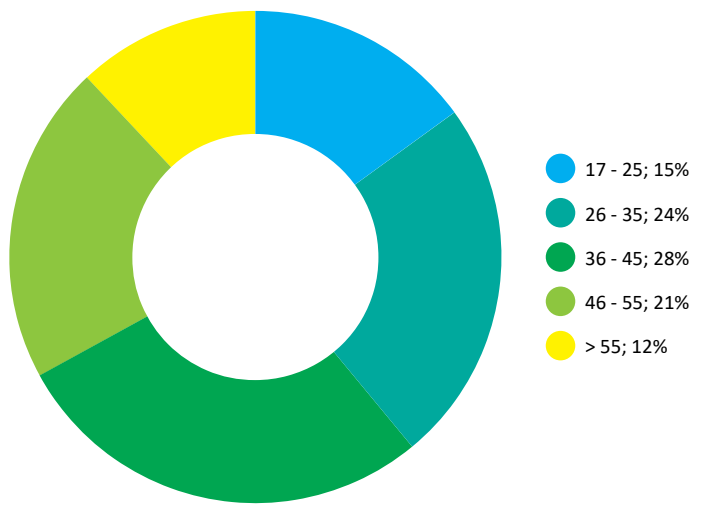

Figure 2. Respondents based on Age

work, and type of services needed. the profile of the respondents then will be related to the measurement results of IKM health services in Banten Province Public Hospital because the respondents are the ones who fill the questionnaire of this research. Here is an overview of respondents in Banten Public Hospital.

The data shows that the comparison between the number of male and female found as respondents are almost equal in number, amounted to $49 \%$ or 49 persons are female and $51 \%$ or 51 persons are male.

When seen from the age, the majority of respondents are in the range of 26 to 45 years old. It also means that most respondents are at the productive age and expected to provide information accurately in accordance with what they perceived. This age group includes productive age, so it usually has a high expectation of the quality of service.

The data shows that most of the respondents or $82 \%$ are married, $15 \%$ are unmarried, and the remaining $3 \%$ used to be married.

The largest distribution of respondents based on the level of education is at the level of senior high school (38\%), and in fact, according to actual conditions in Banten Province, indeed the majority of the education level of Banten community is in junior and senior high school levels (Figure 4).

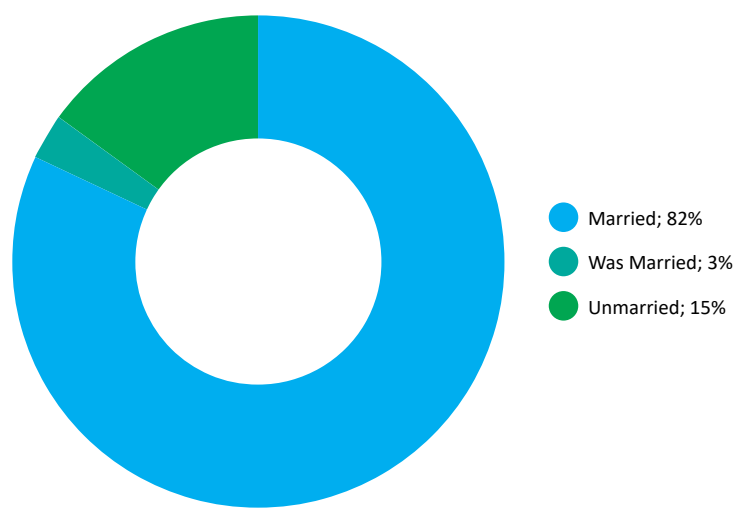

Figure 3. Respondents based on Status 


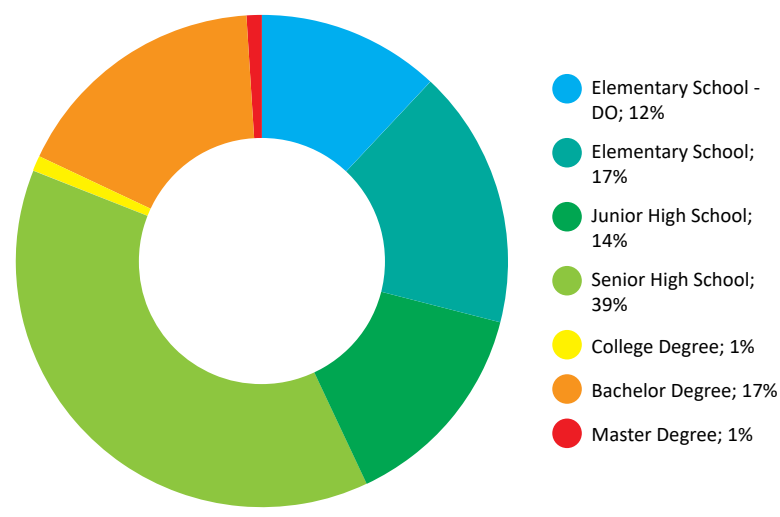

Figure 4. Respondent's based on Education Level

It shows that most respondents work as housewives amounted to $28 \%$, at private sectors amounted to $19 \%, 15 \%$ as entrepreneurs, $13 \%$ as

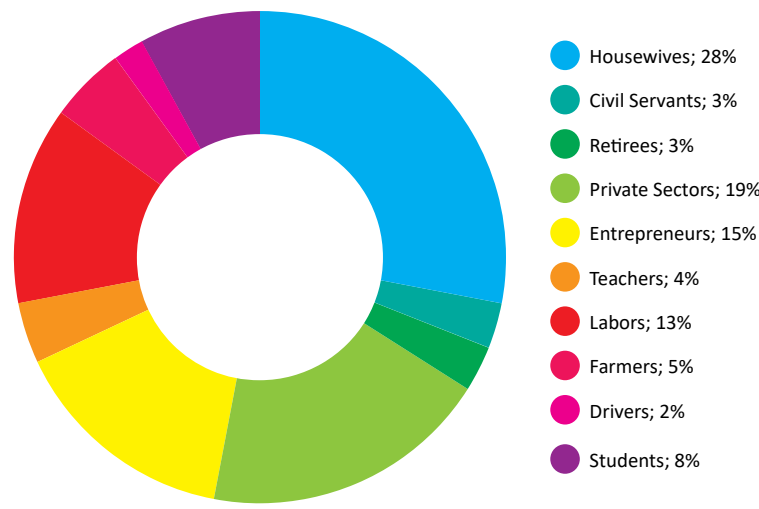

Figure 5. Respondents based on Profession

labors, $3 \%$ are retirees, $3 \%$ are civil servants, $5 \%$ are farmers, $2 \%$ are drivers, $8 \%$ are students, and $4 \%$ are teachers/educators.

Based on the respondent's group income, there are $31 \%$ of respondents who earn less than $\mathrm{Rp} 750,000 ; 18 \%$ of respondents who earn

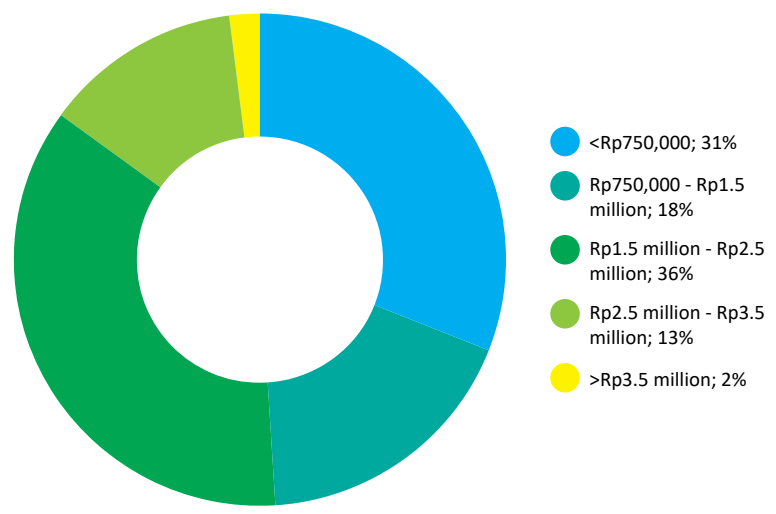

Figure 6. Respondents based on Income

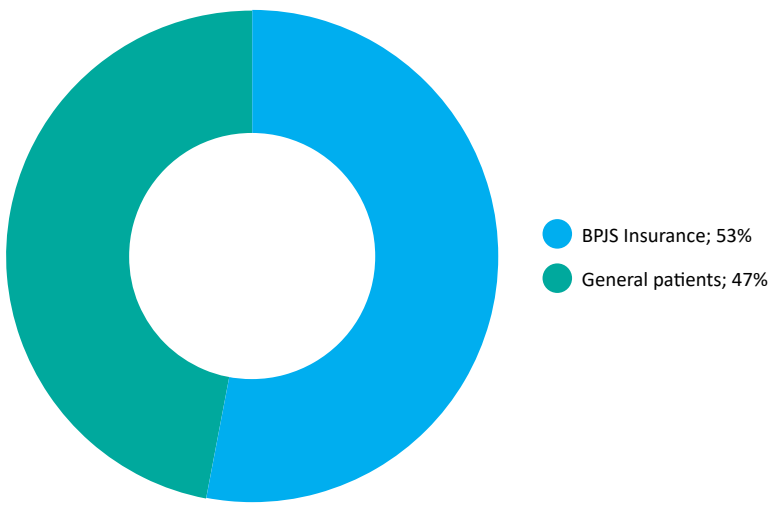

Figure 7. Respondents based on Patient Category

Rp750,000 - Rp1.5 million. Most of the respondents with the earning of an average of Rp1.5 - Rp2.5 million are approximately $36 \%$. The remaining, approximately $15 \%$, earn more than Rp2.5 million.

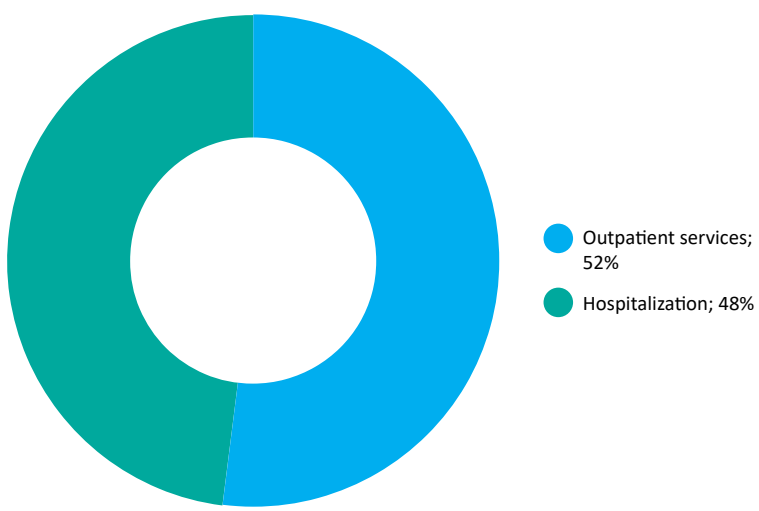

Figure 8. Respondents based on Treatment Status

The diagram above shows that Banten Public Hospital receives more patients with BPJS insurance (53\%) than the general patients or patients who use self-paying service ( $47 \%)$.

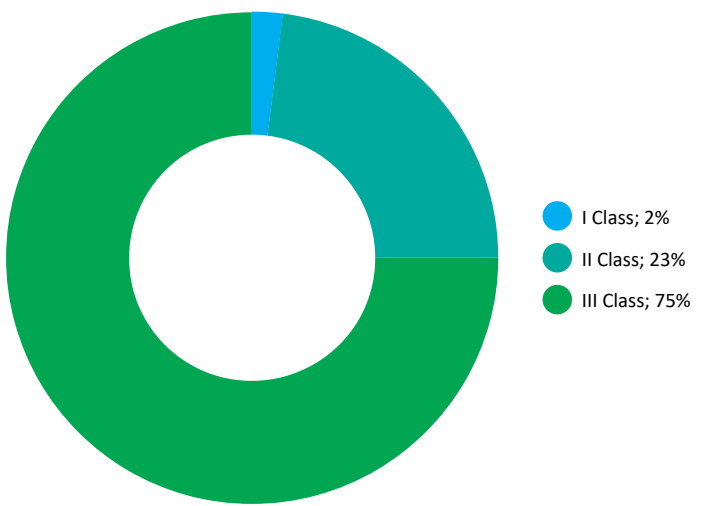

Figure 9. Respondents based on In-Patient Facilities Class

When seen from the type of care, the 
respondents with outpatient services are as much as $52 \%$ and those with hospitalization are as much as $48 \%$.

The data shows that most respondents (75\%) use grade 3 inpatient facilities, 23\% in 2nd class inpatient rooms, and only $1 \%$ use first class inpatient facilities.

\section{Public Satisfaction Index (IKM) in Banten Province Public Hospital}

Public satisfaction is an important aspect for Banten Public Hospital as a public health service provider. The scope of the Public Satisfaction Survey in this study includes: (1) Requirements, namely the requirements that must be met in the management of a type of service, both technical and administrative requirements, (2) Procedures, namely standardized service procedures for the giver and the recipient of services, including the complaint, (3) Service time, i.e. the time period required to complete the entire service process of each type of service, (4) Cost/Tariff, i.e. the fees charged to the recipient in handling and/or obtaining services from the provider in which the amount is specified based on the agreement between the provider and the public, (5) Type of Service Specification Products, i.e. the results of services provided and received in accordance with the established provisions. This service product is the result of each specification of service type, (6) Executor Competence, which is the ability that must be possessed by the executor covering knowledge, skills, capabilities, and experience, (7) Executor Behavior, which is the officers attitude in giving service, (8) ) Service Statement, which is a statement of the willingness and obligation of the provider to perform the service in accordance with the standard of service, and (9) Complaint, Advice and Input handling, namely the procedure of handling complaints and follow-up.

The Public Satisfaction Survey above will be measured comprehensively so that the measurement towards public opinion can be obtained to receive health service from the public service provider, which is Banten Public Hospital. The following is a description of results of the public satisfaction survey at Banten Public Hospital:

\section{1) Service Requirement Element}

This element describes the terms of service provided to the public, which is the conditions that must be met in the management of services, both technical requirements, and administrative requirements. Figure 10 is a description of the community's response to the elements of service requirements.

Figure 10 illustrates the opinions of respondents about the service requirements that

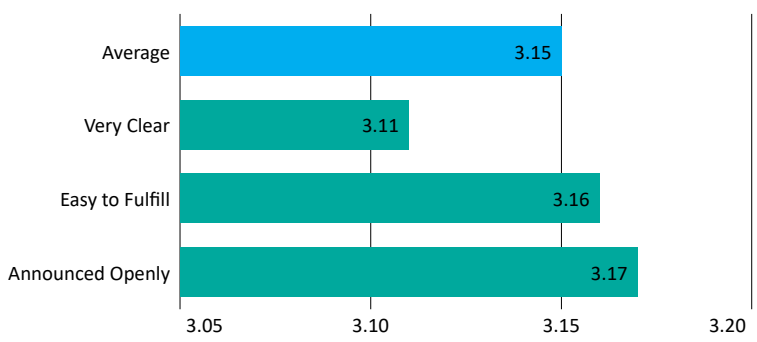

Figure 10. Service Requirement Element

must be met by the community to obtain health services. The result showed that the average assessment of respondents is 3.15 or falls into a good category, and the highest value is on the aspect of information disclosure on service requirements and an ease of service in meeting the requirements required. The following is the explanation of aspects related to the terms of service:

\section{a) Information disclosure on service} requirements

The disclosure of the terms of service is described as a condition in which Information on the terms of service has been publicly announced in a publicly accessible area and contains a complete and clear information. In this aspect, the respondents gave a rating of 3.17 or fall into the category of very good. This means that respondents are satisfied with the information disclosure conveyed by Banten Public Hospital.

b) Clarity of service requirements information

The clarity of service requirements is described as a condition in which information related to service information is clear and not confusing. In this aspect, the respondent gave an assessment of 3.11 or falls into the category of good. However, there are still respondents who do not understand the intended terms of service. This is necessary considering the level of understanding and knowledge of the community is also very diverse, so the service officers need to provide an explanation verbally to people who do not understand about the terms of service.

\section{c) Ease of meeting the requirements}

The ease of requirements is described as a condition in which administrative and technical requirements in obtaining services are easy to fulfill so that the public has no difficulty in obtaining services. As stated by Warella in Wahdania, et. al. 
(2015) that the criteria of quality public services are (1) simplicity, in which the procedures of service are held easily, smoothly, quickly, not convoluted, and easily understood and implemented by the service requester, (2) clarity and certainty about the procedures of service, (3) openness in service procedures.

In this aspect, the respondents also gave a value of 3.16 or fall into the good category. Nevertheless, there are still people who find it difficult to meet the requirements of service.

\section{2) Service Procedure Elements}

This element describes a standardized service
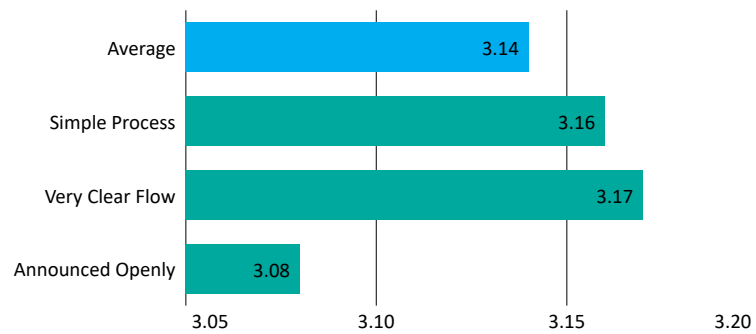

Figure 11. Service Procedure Element

procedure to both the giver and the recipient of the service, including the complaint. The following is the respondent's perception related to the service procedures.

The graph above illustrates that in general, the respondents are satisfied with the service procedure in Banten Public Hospital. Respondents gave appreciation with the average of 3.14. or falls into the good category. The aspects that exist in service procedures can be described as follows:

a) The simplicity of service procedure The simplicity of the service procedure describes how the patients should go through the stages of service and the patients find it easy to get through. From the data found, the respondents gave an assessment of 3.16 or fall into the good category, which means that the respondents are satisfied and the procedures that they have to go through are also not convoluted.

b) Flow clarity on service procedure

In this aspect, the public satisfaction index reached 3.17 or falls into the good category. The clarity of the service flow/ process is considered not confusing and very clear. In general, respondents felt that it was clear enough with the flow that they must go through. But there are still respondents who are not very familiar with the flow that must be met. It is understandable that not all people have sufficient knowledge and insights to understand the flow of service. So, it is better to prepare officers who specifically give information verbally to the people who need clarity on the procedure of service.

\section{c) Information Disclosure on Service}

\section{Procedures}

In this aspect, respondents assess that the hospital has provided a required information on the stages or flows to obtain health services, in which such things are announced at accessible public places in details/clearly, with the score of 3.08 or falls into the category of very good.

\section{3) Service Time Element}

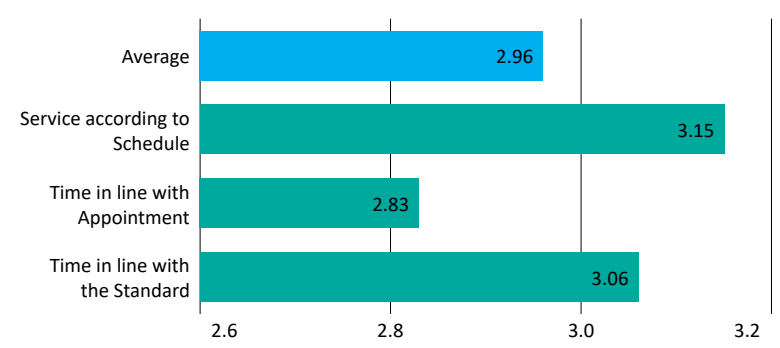

Figure 12. Service Time Element

Service time element illustrated the service time target that can be completed in accordance with the specified time by the service provider unit. Below is the illustration of service time element.

The graph above illustrates in general how the people gave a score of 2.96 or falls into the good category. Below is the explanation of the stated service time:

a) Service on schedule

This aspect relates to the opening hours of service in accordance with a predetermined schedule, which is at 08.00, the time for doctor visits, the time for patients meal, the availability of ambulance, and so forth. In this aspect, respondents are satisfied with the service time, so the respondents gave a score of 3.15 or fall into the good category.

b) Service as promised

This aspect explains whether the 
completion time of the service is timely in accordance with predetermined standards/promises. Respondents considered that the service completion time is in accordance with the predetermined promise, so the respondents gave the score of 2.83 or fall into a good category. Although it is included in the good category, there are still respondents who are dissatisfied with the standards/promises that have been set for the service time to get service.

\section{c) Time according to standard}

Time according to the standard means that the time spent to complete the service

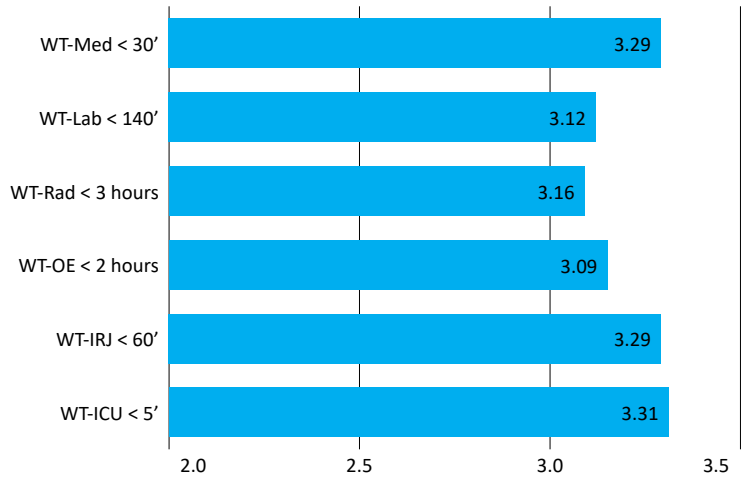

Figure 13. Service Waiting Time Element

is in accordance with the established standards. In this aspect, the respondents gave a score of 3.06 or fall into a good category.

Meanwhile, when seen from the aspect of waiting time for the medicine to be ready, Laboratory, Radiology and so on, respondents gave a good assessment. The highest satisfaction felt by respondents is the waiting time of IGD with a score of 3.31 , followed by the service in Outpatient Installation and ready medicine service with the same score, which is 3.29. While for radiology, laboratory, and elective operations, each is given a score of 3.16 , 3.12 , and 3.09.

\section{4) Cost/Tariff}

Costs/tariffs shall be the fees charged to the recipient of services in the maintenance and/or obtaining of services of the provider where the amount is determined by the agreement between the provider and the people. Here's an overview (Figure 14) that can explain the costs or tariffs to get services.
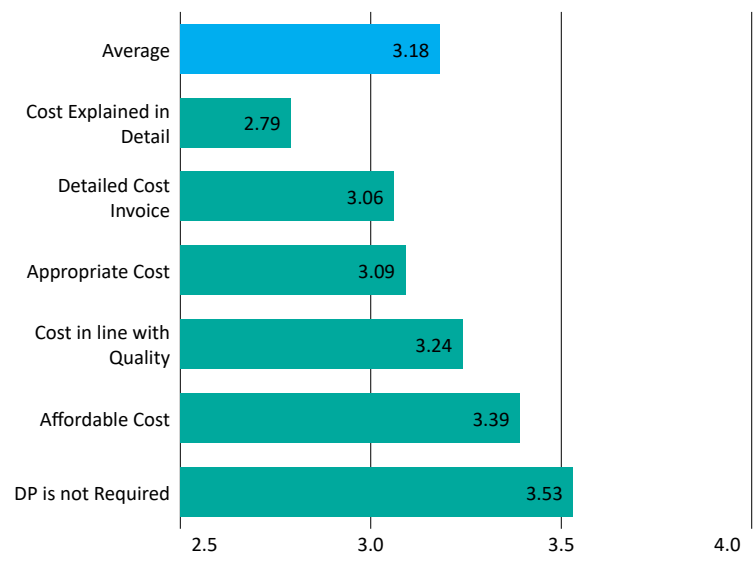

Figure 14. Service Cost Element

On this element, the average respondents gave an assessment of 3.18 or fall into the good category. The following is the description of the service cost.

a) Not required to pay the down payment (DP)

In this aspect, respondents are asked whether before hospital service the patients are obliged to pay the DP or not. Almost all respondents gave the same answer, that they are not required to pay the DP. So, the respondents gave a score of 3.53 or fall into the category of very satisfied.

b) Cost is affordable and in accordance with quality

Respondents are asked about the amount of fee charged to them. The average respondents replied that the fees charged can be afforded by them. Therefore, the respondents gave an appreciation of 3.39 or fall into the category of very good.

c) Cost is in accordance with the quality of service

Respondents also felt that the amount of cost incurred was very much in line with the quality of service received. This is reflected in the assessment given by the respondents of 3.24 (very good).

d) Fairness of service cost

The fairness of the service cost is the respondents' perception of the standard cost incurred when compared to other service providers. In this aspect, the respondents considered that the cost of service in Banten Public Hospital is still considered reasonable. So, the respondents gave a fairly high appreciation of 3.09 or fall into the category of fair. 
Related to this, Azwar (1996) argued that in order for the provision of health services to achieve the desired goals, the service must meet various requirements, including: available and sustainable, acceptable and reasonable, easy to achieve, easy to reach, and of quality.

e) Given an invoice and explained in detail Similarly, with the question of whether the patients are given an invoice and explained in detail the cost of services that must be paid by the patients. Therefore, the same answer is also conveyed that Banten Public Hospital always provides invoices and details of the cost. In both of these aspects, respondents gave a good appraisal of 3.06 for the service fee, and 2.79 for the detailed explanation of service cost.

\section{5) Type of Service Specification Products}

Type of Service Specification Product is the result of services provided and received in accordance with the provisions that have been set.

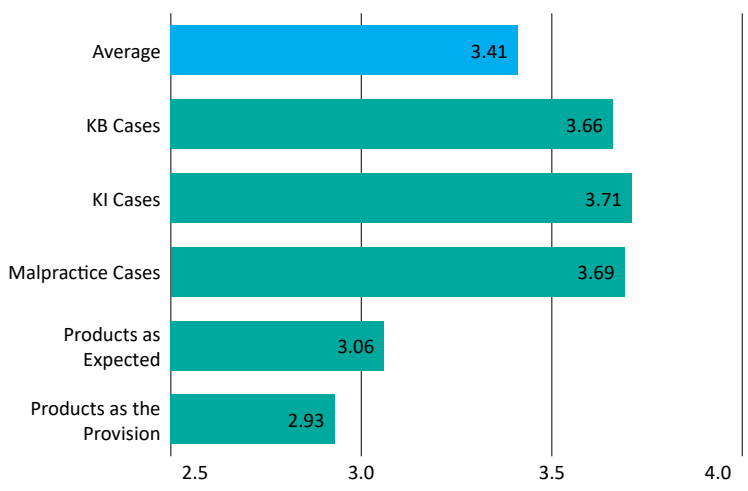

Figure 15. Service Type Specification Element

This service product is the result of each service type specification. The following describes the description related to service type specification product in RSUD Banten:

The graph above illustrates how the respondents respond to the specification of the type of service. Here is described the element.

a) Service products in accordance with the terms and expectations

This aspect describes the responses of respondents about the results of services received/perceived, whether it has been in accordance with the applicable provisions (no errors or violations of regulations). The survey results show that respondents are satisfied with the services they need. They think that the health services provided by the Banten Public Hospital have complied with the applicable regulations. So, the respondent gave a score of 2.93 or fall into the good category. Likewise, with the expectations of patients, respondents also feel the service provided is in accordance with the expectations of patients. Nevertheless, there are still respondents who expect Banten Public Hospital services to keep improving.

b) Never heard of malpractice cases

The next question is directed to whether the respondents ever heard of malpractice cases or cases of maternal death or death of a child/toddler. Almost all respondents answered that they never heard of the mentioned cases. A small part answered did not know. So in this aspect, the respondents rate very high fall into the very good category, which is equal to 3.69 for malpractice cases, 3.71 for maternal mortality cases, and 3.66 for cases of death of children/toddlers. This indicates that the Banten Public Hospital has made various efforts to maintain public confidence, and it is evident that people have started to feel satisfied with the quality of their services.

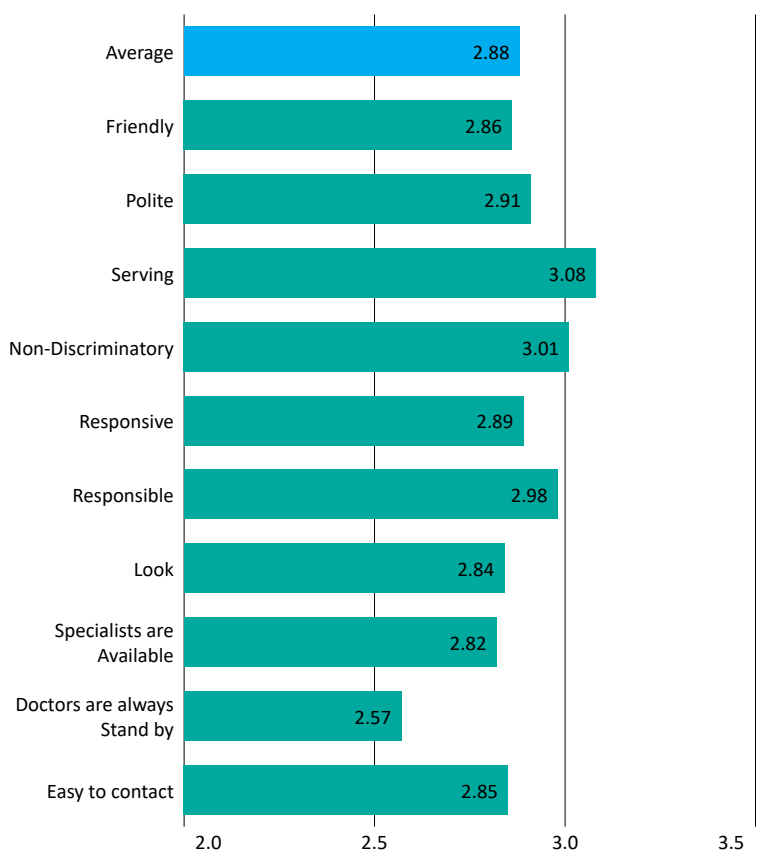

Figure 16. Service Officers' Behaviour Element 


\section{6) Executor Behavior Element}

Executor behavior is the attitude of officers in providing services. Here are the findings obtained in the field.

In general, the behavior of service officers in Banten Province Public Hospital fall into the good or satisfactory category with a score of 2.88. This indicates that the staffs of the Public Hospital have prepared themselves as best as possible in carrying out their duties.

a) Officers are easy to contact and doctors are always on standby

This aspect shows the respondents' response to the question of whether service personnel is readily accessible at all times, and whether the doctors on duty are always present on every schedule. Respondents considered that officers and doctors are easy to contact, and they/respondents gave a score of 2.85 and 2.57 or included in the good category. Nevertheless, there are still respondents who judge that when they need the service, it is not easy to contact the officers, and for the doctors in charge of hospitalization, they are not always standby in place of duty.

b) Responsibility and non-discrimination With regards to behavior, then the respondents asked the question whether the service officers have a responsibility and are not discriminatory. Respondents assume that in providing service officers, they do not show discriminatory attitude to the patients. Similarly, to the responsibilities shown. Therefore, the respondents gave a score of 3.01 and 2.98 respectively or fall into the good category. Nevertheless, there are still respondents who feel distinguished in the provision of services by officers.

c) Courteous, friendly, and ready to serve The aspects of courtesy and hospitality of officers are also rated well by the respondents. This means that respondents are satisfied with the courtesy and hospitality of the healthcare workers in the hospital. In line with the one presented by Djoko Wiyono in Wahdania et al (2015), one of the implementations of excellent service in the field of health is always for the officers to provide services with a friendly and polite attitude and strive to improve service performance optimally with service capabilities in the sufficient number and type. In other words, the service personnel in the service should be nice, polite, friendly, and do not put a sour face in front of the patient and listen to the patient's complaints and overcome them in a wise manner and in accordance with the rules and regulations that apply.

Each aspect is rated 2.91 and 2.88 . However, in both aspects, there are still respondents who rate officers less friendly and tend to be less patient in dealing with the patients. In the aspect of responsiveness (ready and standby to serve), the score given is 3.08 and falls into the category of good.

\section{7) Service Officers Competence Element}

Competence of service personnel is the ability that must be possessed by the provider of services,

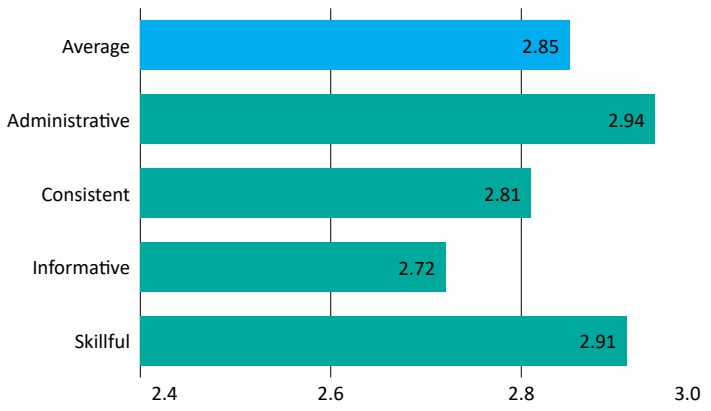

Figure 17. Service Officers Competence Element

which includes knowledge, skills, capabilities, and experience. Here are some aspects related to the competence of service personnel at Banten Province Public Hospital based on findings in the field.

In general, respondents gave a score of 2.85 . Although it is still in the good category, the score is below 3.00. This is partly related to the competence of Banten Province Public Hospital personnel, such as not all nurses of IGD (only about 86\%) have attended BLS (Basic Life Support) training, BCLS (Basic Cardiac Life Support), or PPGD (First Emergency Relief). Related to that, the aspects that need attention are:

\section{a) Administrative ability}

Administrative ability is the ability of officers in managing information related to patients' data, medical records, and so on. This ability is seen when the patient does the registration up to the completion of the service. Respondents assume that the service personnel already have the intended administration capability, so the respondents gave a score of 2.94 or fall 
into the category of good.

\section{b) Consistency between officers}

Consistency between officers means that there are similarities between information and action between officers. Where there is no difference or inconsistency, either on information or medical action. In this aspect, the respondents gave a score of 2.81. although it still falls into the good category, since the average score is below 3.00, it needs serious attention. It means that some respondents still find inconsistency and miscommunication among service personnel.

\section{c) Informative skills}

Informative ability is the ability to provide information in a straightforward and clear manner to the patients who need it. In this aspect, the respondents gave the lowest score for the competence element of the service officer, which is equal to 2.72 or below the average of the competence of the officer in general. This indicates that officers need to improve the ability to convey information so that what is delivered by the officer can be immediately understood by the patients and the family.

\section{d) Skillful, thorough and meticulous}

Then the respondents were asked about whether in giving service, the officer seemed skillful, thorough, and meticulous (as seen from how skillful and serious and convincing the personnel in performing the task). Respondents gave a score of 2.89. This indicates that indeed, respondents still expect improvement in the skill, accuracy, and precision of the implementing officers.

\section{8) Elements of Service Information and Complaints Handling}

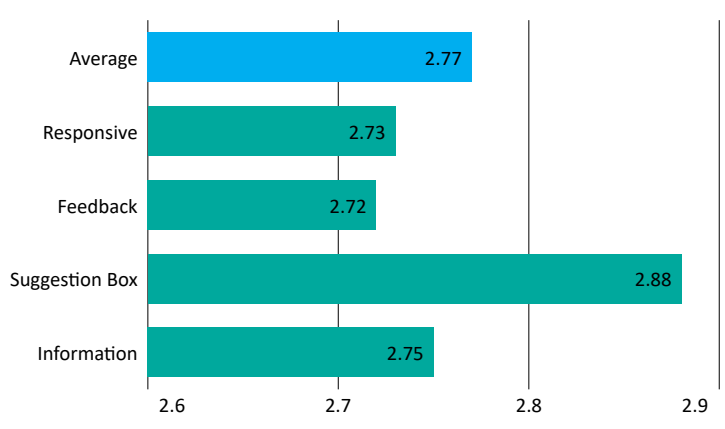

Figure 18. Information and Complaints Handling Element
Service information is a statement of ability and obligation of the provider to organize services in accordance with service standards. Here is a description of respondents' assessment of the service by Banten Public Hospital and how the complaints are handled:

In general, averagely, information and complaint handling are given a value of 2.77 or fall into the category of quite good. Here is an explanation of the findings obtained in the field:

\section{a) Information of service}

Banten hospital has conveyed the service information and the public as the service users are already familiar with the information. So, the respondents gave a score of 2.75 or fall into the good category.

\section{b) Suggestion box}

The Public Hospital has also prepared a suggestion box for the people who want to file a complaint with the hospital. So, the respondents also gave a score of 2.88 or fall into the good category.

\section{c) Feedback and response as expected}

Although the score for the feedback element amounted to 2.72 or fall into a good category, most respondents felt less satisfied because the Public Hospital does not immediately provide feedback on complaints from the public. Likewise, with the response given is in accordance with expectations, the score obtained is equal to 2.73 or fall into the category of good. However, respondents felt that even if the complaint was responded by the hospital, it did not meet the patient's expectation yet. This means that the feedback on complaints from the community must be responded immediately, and the response must be straightforward, so the community becomes very satisfied with the health services provided by the Banten Province Public Hospital.

\section{9) Supporting Element}

This element explains the comfort in Banten Province Public Hospital. Figure 19 is the illustration of the respondents' response towards the supporting elements in Banten Public Hospital.

In this element, the average score given is 2.92 or fall into the category of good. However, Banten Public Hospital needs to pay more attention in providing convenience for service users related to some elements of the infrastructure. Here's a comprehensive explanation: 


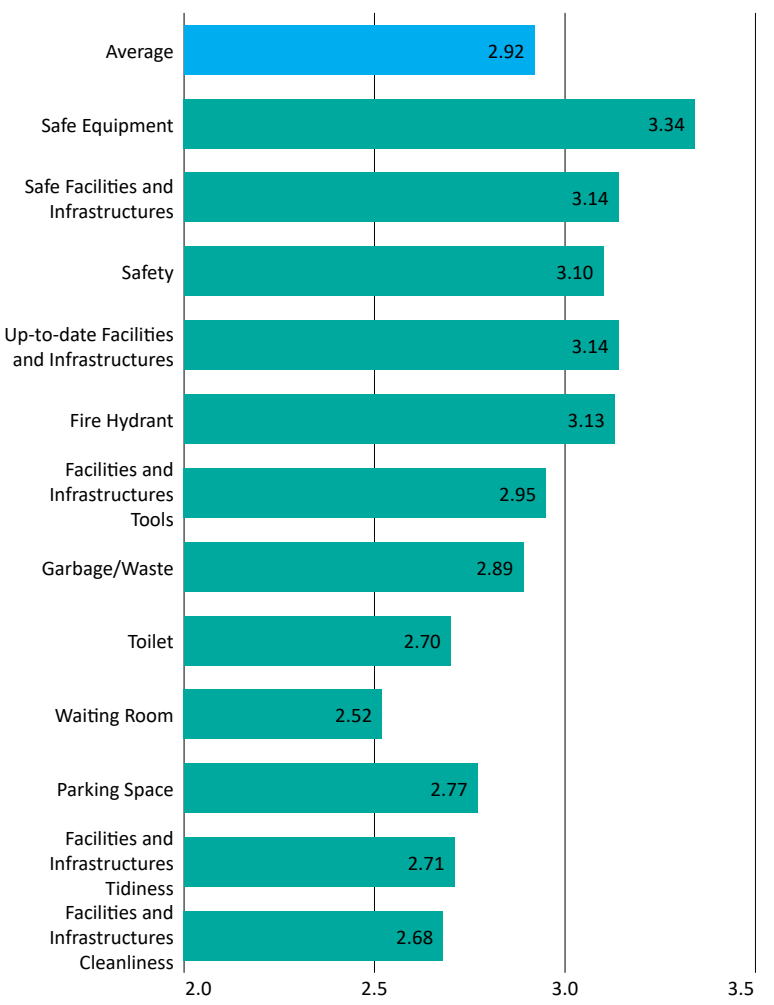

Figure 19. Service Supporting Element

a) Safe equipment and infrastructure facilities

As a health service institution, of course, A hospital is required to provide the best service possible because it involves someone's life. In terms of equipment and infrastructure facilities, the respondents are asked whether the equipment and infrastructure endanger the visitors and patients or not? For example, the condition of the slippery floor, the patient's bed that can cause a fall, electrical cable installation that is not tidy so it can be dangerous, and so on. In this aspect, the respondent gave an assessment of 3.34 and 3.14 or fall into the good category, meaning that the condition of equipment and infrastructure in the hospital area does not endanger the visitors and the patients at the hospital.

b) Security

Respondents rated it 3.10. Despite being categorized as good, respondents expect Banten Public Hospital to improve security in its environment.

c) Up to date infrastructures \& facilities Respondents gave a good assessment of this element. A score of 3.14, which means that the existing facilities and infrastructures in Banten hospitals are considered up to date.

d) Availability of fire extinguishers

Respondents rated it 3.14. This indicates that respondents feel that in every fireprone hotspots, there is a fire extinguisher, although in a limited number.

e) Completeness of infrastructure facilities Respondents rated 2.95 to this element and it is categorized as good. Nevertheless, there are still complaints about the completeness of facilities and infrastructures that are in the hospital environment, for example, bedrooms for family patients are not provided as in other hospitals. There is no playroom available for children, so the visitors or patients who bring toddlers feel uncomfortable because of the "noise" caused by the children who play inside the hospital area. Similarly, about canteen, it turns out that Banten Public Hospital has not provided a canteen to eat for the visitors and the companions of patients, so it is very difficult for them to eat there.

\section{f) Waste management}

Respondents rated 2.89. Although the value falls into the category of good, the hospital should pay more attention to hygiene, especially on its waste management considering some criticism of the respondents on this issue. The waste is ordinary rubbish and medical waste. Related to this matter, Djoko Wijono in Wahdania, et al (2015) explains that one of the implementations of the excellent service in the field of health is on the cleanliness and sanitation of the environment, in which the service facility should always be guaranteed through routine hygiene and control of waste disposal facilities.

In this aspect, the respondent rated 2.70 or still into the category of good. Nevertheless, the respondents complained about the existing toilet that was not functioning, dirty, and stinking.

\section{h) Waiting Room}

Respondents rated the least on this aspect when compared to other aspects, which amounted to 2.52. Although the value still falls into the category of good, the value 
is still very far below the number 3.00, so the hospital should also give more attention to facilities and infrastructure in the waiting room. When seen from the cleanliness of the waiting room, it is still maintained. However, respondents complained the waiting room, which is considered narrow, hot, crowded when queuing for doctors for treatment, and with limited seating provided. The capacity of the waiting room is unable to accommodate patients and families of patients who come. So, the respondents expect the hospital to improve the comfort of the waiting room.

\section{i) Parking}

In this aspect, the respondents gave a score of 2.77 or included in a good category. However, respondents still doubt the safety of vehicles in the parking area. Parking facilities are also very basic and not made as comfortable as possible for riders. This requires the hospital to pay attention to parking facilities for both visitors and patients.

\section{j) Cleanliness and tidiness}

Then, when asked about the cleanliness and tidiness of the hospital environment, each got a score of 2.71 and 2.68. Although these two aspects still fall into the good category and are good enough, they are still below 3.00, so it needs attention. Respondents admitted there are still places which cleanliness are not maintained, such as hallways, waiting room, and even in the treatment room. Then, many also questioned about the toilet that did not work and the cleanliness is not well-maintained. They find it difficult when they need a toilet, hoping the hospital can clean and repair the toilet to be used again.

From the description of the dimensions or elements of IKM above, it can be concluded how the respondents' perception of the quality of health services provided by Banten Public Hospital, as illustrated in Figure 20.

The score values obtained in the graph then converted into a maximum unit value of 100 . Then, the value of IKM can be presented after conversion as follows.

Based on both graphs, can be seen that the value of community satisfaction index (IKM) of Banten Province Public Hospital is amounted to 75.71 or included in the category of Good. Of the 10

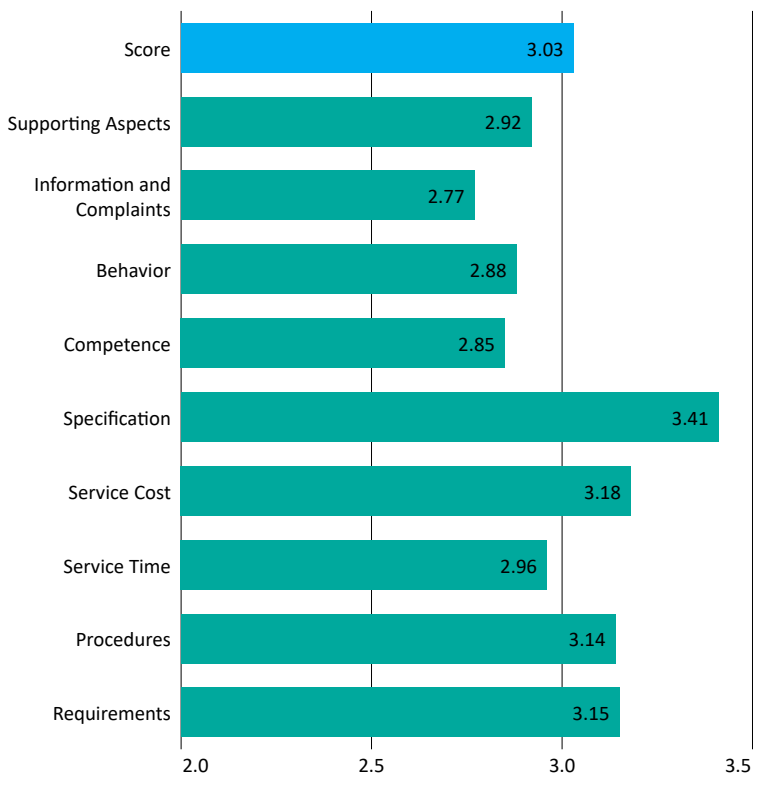

Figure 20. Public Satisfaction Index towards Banten Public Hospital Services

elements assessed, service products specification elements need to be appreciated. Respondents felt that the service products provided are in line with their expectations. This is in accordance with the finding proposed by Supranto (1997: 224) that the performance of goods is at least the same as what is expected. Then, there are still two elements that should be considered further by Banten Province Public Hospital, namely handling complaints and aspects of competence, because each element gets the lowest score when compared to other service elements. Indeed, when seen from the information provided, the RSUD has provided and plastered it in front of the entrance in the form of banners.

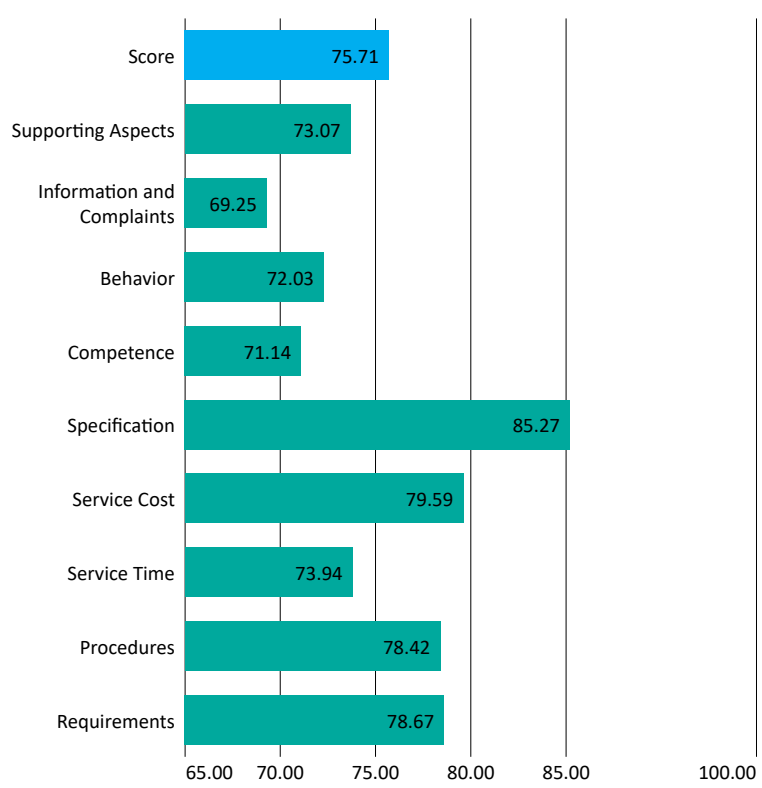

Figure 21. Public Satisfaction Index towards Banten Public Hospital Services 
However, if there is a complaint from the service users that the hospital has not been sufficiently responsive to the complaints, or the responses given by the hospital have not met their expectation. Another element that needs attention is the element of competence. Respondents still assess lower when compared to other elements that amounted to 71.14 or included in a good category. Nevertheless, there are still many complaints from service users related to this element of competence.

In general, can be analyzed the performance per element of service in RSUD Banten Province, where there is a significant disparity between the ten elements assessed. Elements of service are the element that is not well managed, but this element is relatively easy to manage. Similarly, the element of handling complaints has a very real disparity with elements of service products, in which that performance is quite optimum and is included in a very good category. Similarly, the behavioral elements of service personnel, the competence of service personnel, service time, and supporting elements generally still need to be considered given the disparity with other elements.

Based on the above data exposure, the disparities encountered in the practice of health care services need to get serious attention from Banten Public Hospital because they are related to the quality of public services and the failure in the sale of services, as stated in a theory by Parasuraman, Zeithaml and Berry (Alma, 2002) which explains that there are five gaps that can lead to the failure of service sales, namely: 1) consumer expectation gap and management perception, 2) management perception gap and service quality, 3) service quality gap and service delivery, 4) service delivery gap and external communication, 5) service gaps experienced/perceived and services expected.

\section{Conclusion}

The result of this study indicates that the quality of public services organized by Banten Public Hospital based on Community Satisfaction Index, quantitatively reached 75.71 , which is qualitatively categorized as good. Thus, the 5 (five) lowest index elements that need attention are information, complaint handling, service officer behavior, service time, and supporting elements.

\section{ACKNOWLEDGEMENT}

We would like to thank Bappeda Banten Province which has facilitated activities funded by Banten Province budget, which results can be reported through this paper. And also, to all parties for all the help and support.

\section{REFERENCES}

Alma, B. (2002). Manajemen Pemasaran dan Pemasaran Jasa. Bandung: Alfabeta.

Arisandy, W. (2015). Strategi Dinas Kesehatan dalam Meningkatkan Kualitas Pelayanan Kesehatan melalui Metode CRC (Citizen Report Card) di Kota Surabaya. Kebijakan Dan Manajemen Publik, 3(2), 12-23. Retrieved from http:// journal.unair.ac.id/KMP@strategi-metode-crc(cityzen-report-card)-dinas-kesehatan-dalammeningkatkan-kualitas-pelayanan-kesehatandi-kota-surabaya-article-8994-media-138-category-8.html

Dumupa, Y., Harno, \& Budi, H. S. (2014). Hubungan Kualitas Pelayanan Asuransi Kesehatan Terhadap Kepuasan Pasien Pengguna Jaminan Kesehatan Nasional (JKN) di RSUD Prambanan Kabupaten Sleman Tahun 2014. Jurnal Permata Indonesia, 5(2), 15-23. Retrieved from http:// www.permataindonesia.ac.id/wp-content/ uploads/2015/07/201403.pdf

Herawan, I. G. A. W., Hutabarat, J., \& Gustopo, D. (2017). Analisis Kualitas Pelayanan di Puskesmas X Menggunakan Metode Servqual dan Saran Perbaikannya. Jurnal Teknologi Dan Manajemen Industri, 3(1), 34-40. Retrieved from http://ejournal.itn.ac.id/index.php/jtmi/ article/view/462

Hubung, H. (2015). Kualitas Pelayanan Kesehatan pada Puskesmas Kampung Baqa Kecamatan Samarinda Seberang Kota Samarinda. eJournal Ilmu Administrasi Negara, 3(5), 14371451. Retrieved from http://www.e-jurnal. com/2016/02/kualitas-pelayanan-kesehatanpada.html

Media, Y. (2014). Kualitas Pelayanan Kesehatan Ibu Hamil dan Bersalin di Daerah Terpencil (Studi Kasus di Nagari Batu Bajanjang, Kabupaten Solok, Provinsi Sumatera Barat). Jurnal Bina Praja, 6(1), 21-30. http://doi.org/10.21787/ JBP.06.2014.21-30

Pasolong, H. (2015). Teori Administrasi Publik. Bandung: Alfabeta.

Pundenswari, P. (2017). Analisa Pengaruh Kualitas Pelayanan Publik Bidang Kesehatan terhadap Kepuasan Masyarakat. Jurnal Publik, 11(1), 13-21. Retrieved from https://journal.uniga. ac.id/index.php/JPB/article/view/2/

Ratminto, \& Winarsih, A. S. (2016). Manajemen Pelayanan: Pengembangan Model, Konseptual, Penerapan Citizen's Charter dan Standar Pelayanan Minimal. Yogyakarta: Pustaka Pelajar.

Saptawan, A., \& Nengyanti. (2014). Efektivitas Kualitas Pelayanan Kesehatan Masyarakat. Jurnal Imu Administrasi Negara, 12(4), 241255. Retrieved from https://ejournal.unri. 
ac.id/index.php/JIANA/article/view/2213

Supartiningsih, S. (2017). Kualitas Pelayanan an

Kepuasan Pasien Rumah Sakit: Kasus pada

Pasien Rawat Jalan. Jurnal Medicoeticolegal

Dan Manajemen Rumah Sakit, 6(1), 9-14.

http://doi.org/10.18196/jmmr.6122

Tjiptono, F. (2016). Manajemen Jasa. Yogyakarta: Andi.
Ulfa, S., \& Zulkarnain, A. K. (2016). Analisis Kepuasan Pasien Rawat Inap Pengguna Jaminan Kesehatan Nasional Terhadap Kualitas Peayanan di Bangsal Kebidanan dan Kandungan RSUD Sleman Yogyakarta. Majalah Farmaseutik, 12(2). Retrieved from https:// jurnal.ugm.ac.id/majalahfarmaseutik/article/ view/26451 